\title{
Algological Studies in the Cave of Mátyás Mount, Budapest, Hungary \\ LAJOS HAJDU ${ }^{1}$ )
}

With two figures in the text

\section{Introduction}

For the botanists it seemed almost impossible to imagine that chlorophyll-containing plants could live in the eternal darkness of caves. We have only a few records from the past which deal with the occurrences of algae in caves (Morton, 1925; or Magdeburg, 1929-1932). Newer investigations are also rather scarce concerning this very interesting biochor. In Hungary, up till 1953, no one had worked on cave algae, though Kol (1957) already in 1951 started her investigations of the ice cave at Telkibánya in the Sátor mountains. In this cave, however, some light penetration occurs and thus it cannot be considered in the same category as those in which there is eternal darkness. In his definitive work about the Baradla cave at Aggtelek, Dudich (1932) mentions that he could not find algae even in the areas close to the entrance. Similarly, Jakucs (1952) in his enumeration of the plant life of the Baradla cave mentions that iron and sulphur bacteria and some fungi are known from the cave but the algae are not dealt with.

The systematic studies of algae living in dark eaves in Hungary were started in July of 1953, through the initiation of Palik. Claus (1955), in his work on the Baradla cave, mentions the presence of 69 algal species or lower categories. The algological investigations of the cave of Abaliget were also started in the same year (Claus, 1962 b). The number of the algae identified was 93 , whereas the investigations of the Peace cave (Claus, 1962 a), which were started in 1954, resulted in the discovery of 90 algae and the small cave of Pálvölgy (Suba, $1957)$ in the next year disclosed the presence of 41 algal taxa. The investigations of the cave Kölyuk at Mánfa, initiated in 1955, resulted in the identification of 28 species (Claus, 1960), one of which Gomontiella magyariana was not only new to science, but was found to be the third species of a rather rare genus.

1) Microbiological Institute L. Eötvös University, Budapest, Hungary. 
These studies firmly established the existence of algae in caves but could not give any definite answer to the problem of energy utilization. The various authors enumerated above mention four possibilities for the energy utilization.

1. Use of some wave lengths of the electro-magnetic spectrum besides visible light. The radioactivity measurements conducted both in the Baradla and Peace caves, however, seemed to have ruled out this possibility. The idea of Fehér (1954) about the possible existence of a microwave radiation which could be utilized by plants, but is undetectable with our present instruments, cannot be ruled out completely though it seems somewhat unlikely.

2 . The theory of symbiosis between autotrophic iron bacteria and auxotrophic algae was put forth by Magdebur (1929-32) but subsequent workers could not confirm it.

3. Heterotrophic growth is a possibility, the algae making use either of a small amount of available organic matter carried into the caves or utilizing partially decomposed material which arises as a result of bacterial or fungal activity.

4. Chemosynthesis is also a possibility and some algae may make use of it by oxidizing molecular hydrogen from the atmosphere if they contain hydrogenase enzyme (Palik, 1960a).

The major aim of this investigation, besides the gathering of data about the algal flora of the cave of Mátyás Mount, was to supply experimental results about the question of algal assimilation in the darkness of the caves. It was pointed out earlier (Palik, 1960a) that a drawback of all the previous investigations was that the studies were not conducted in situ, but represented laboratory results. Taking this fact into consideration, the experiments described below were carried out in the cave itself.

\section{Description of the Cave of Mátyás Mount}

The cave of Mátyás Mount is located on the southwest side of Mátyás Mount in the Obuda district of Budapest, Hungary. The entrance of the cave originates from a stone quarry and is usually closed with an iron gate in order to prevent unauthorized visitors. The cave can be divided into three main portions. Its oldest known part is called the Fireman Cave, which was discovered in the 1920's. During World War II, when extensive shelter buildings were carried out in the mountains of Obuda, an air raid shelter was developed in portions of the cave by breaking through some unaccessible passages. 
The largest portion of the cave was discovered in 1948 and is called the Centenary Portion.

According to its development the cave can be classified as a reef cave which came to being through tectonic forces. The such formed lithoclasts were further broadened through the eroding activity of thermal waters breaking into them. After the nivo of these thermal waters descended the hot springs disappeared from the cave and surface inflows appeared in the corridors. By now through the corridors of the cave there is a permanent river flowing, which still actively erodes and broadens the corridors. The water flows of the cave are collected in Silty Lake, located at $111 \mathrm{~m}$. above sea level.

Most portions of the cave are excavated in upper Eocene, nummulinic limestone whereas its upper corridors reach into the above lying Eocene bryozoic marl. At two points of the cave (Fireman Corridor's lowest portion and in the river bed leading to Silty Lake) one can find a narrow layer of upper Triassic limestone containing greyish yellow colored hornstone lentils (Jakucs and Kessler, 1962).

According to my measurements the yearly average temperature is $11.6^{\circ} \mathrm{C}$., which is surprisingly high. One may mention in comparison that the average temperature of Baradla Cave is only 9.5 $\mathrm{C}$. The relative humidity varies between 95 to 100 percent. At certain portions, however, even over saturation of the air may occur, especially at places of siphon enterings. The draft varies considerably, from 0 to $80 \mathrm{~m}$. per second. This variation in the draft depends on the temperature difference existing between the surface and the cave interior, on the atmospheric pressure and on the opened or closed state of the entrance door. However, there are quite a few well isolated rooms in the cave where there is practically no air movement. The waters are acidic and their $\mathrm{pH}$ varies between 5 and 6 .

The topography of the cave and its vertical section as drawn by Sándor Jaskó are shown in Figures 1 and 2. In Figure 1 the localities of the collections and the places where cultures were installed into the cave are also marked. 

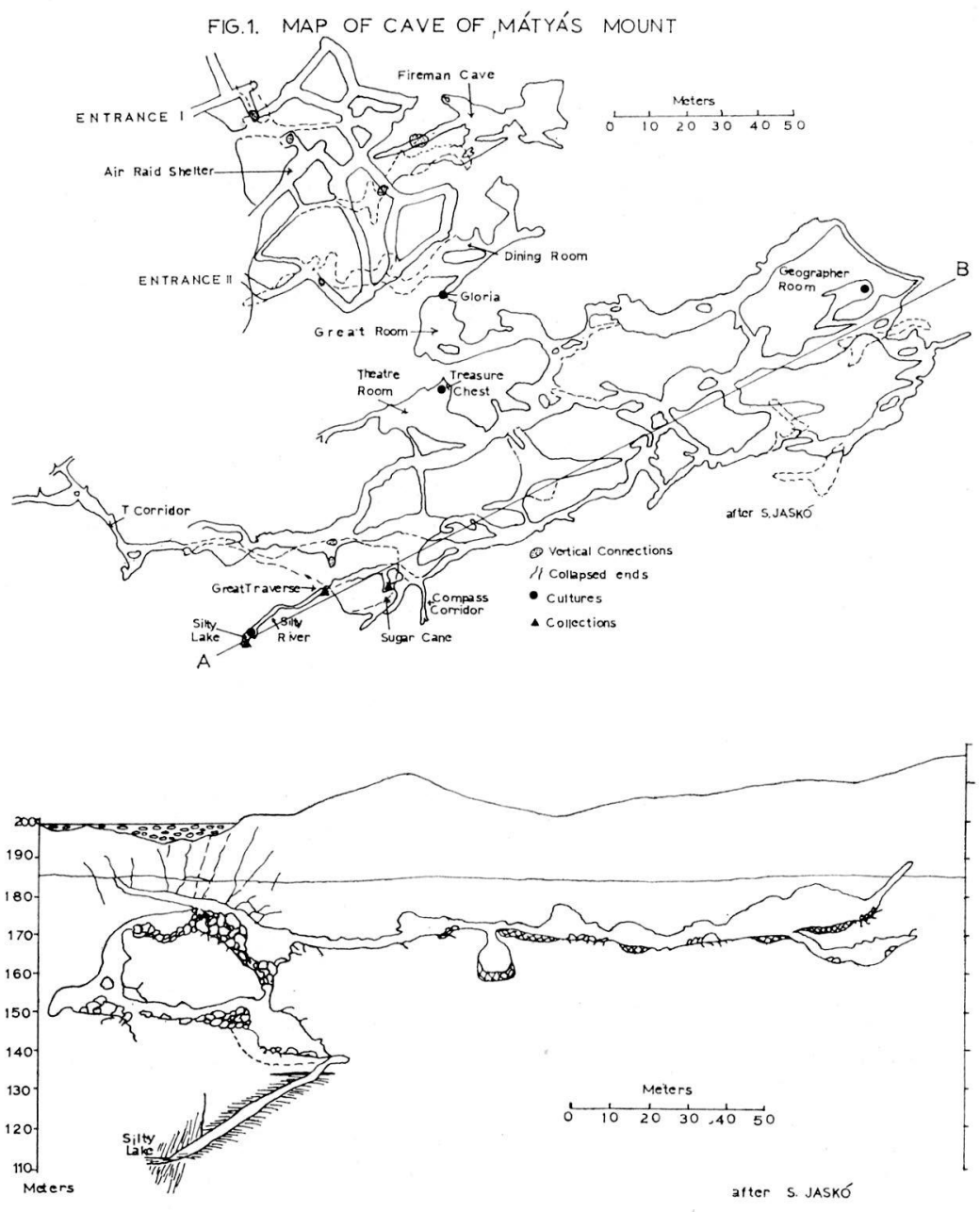

FIG.2. A-B LONGITUDINAL SECTION

\section{Materials and Methods}

Since the ecology of the cave of Mátyás Mount had not yet been investigated, systematic measurements of relative humidity, air current flow, temperature of the air and soil, and $\mathrm{pH}$ of the waters of the cave were taken for a year.

For observing algal multiplication in the cave environment and determining its dependence on the biotopes, several different experiments were conducted. Tubes containing Knop's solution and solidi- 
fied with gelatin were stab inoculated with a pure culture of Scenedesmus obtusiusculus originating from the Biological Institute of Tihany. After inoculation the tubes were wrapped in black paper and were placed on August 22, 1963 in four different biotopes in the cave to test whether or not these have any effect on algal growth. Naturally, the wrappings were removed. Two tubes serving as control were left on the surface, on unwrapped and the other left wrapped in black paper.

The four tubes had the following localities:

1. "Gloria". This term refers to an isthmus approximately half a meter square which connects the "Great Room" and the "Dining Room". By its position this locality has a rather strong draft reaching 80 meters per second. The relative humidity is $95-96 \%$, temperature between $11^{\circ} \mathrm{C}$. and $12^{\circ} \mathrm{C}$. Its distance from the entrance is 75 meters.

2. "Back Room". This is the driest area of the cave, having a relative humidity of 89 to $94 \%$. The temperature is $11^{\circ} \mathrm{C}$. to $12^{\circ} \mathrm{C}$. No measurable draft occurs. It is about 50 meters from the entrance.

3. "Cane Sugar". This biotope is characterized by its high humidity, which is the result of the presence of seeping water on all the walls. Accordingly the relative humidity is 96 percent to over the saturation point. The temperature is $12{ }^{\circ} \mathrm{C}$., no measurable draft occurs, the distance from the entrance is about 200 meters.

4. "Silty Lake". The relative humidity is always around 100 percent, temperature between $11.5^{\circ} \mathrm{C}$. and $12^{\circ} \mathrm{C}$. No appreciable draft occurs. Distance about 350 meters from the entrance. The culture was floated on cork stoppers in the water of the lake, which has a temperature range of $6.5^{\circ} \mathrm{C}$. to $7^{\circ} \mathrm{C}$. The localities of the cultures are indicated on Fig. 1.

The other cultures were placed under rock protrusions and were buried up to two thirds in the speleo-clay. By this the tubes were both protected from accidental discovery on the part of tourists and also from the light that the lamps of visitors may have shed upon them. During the course of the experiments, special care was taken to not disturb or contaminate the biotopes of the cave with surface algae.

In order to decide quantitatively whether or not algae carried into the cave from the surface could grow in the dark speleo environment, the following experiments were carried out. Sterile Knop's solution in test tubes was inoculated with mixed, bacteria free Chlorella culture (composed of possibly three Chlorella species). As described in the previous experiments, the test tubes, after inoculation, were wrapped in black paper and carried into the cave in this state. Four such pre- 
parations were placed, on December 22, 1963, in the "Geographer Room" of the cave. One control tube was left on the surface and another one still wrapped in black paper was placed beside it. The test tubes in the cave were placed similarly to the previously mentioned experiment, under protruding rock surfaces, and were buried into the clay to two thirds of their length.

For measuring the multiplication of the algae a portable nephelometer was constructed and the transmitted light of the cultures prior to their burial, but already in the cave was measured. The meter gave readings in lux. After approximately three months, on March 8, 1964, the cultures were measured again for their light transmittance.

To test whether or not the presence of a strong magnetic field or the complete absence of such has any influence on the development of algae in caves, on February 6, 1964, cultures were placed in the same locality where the previous experiments were conducted between the poles of strong permanent magnets. Several other cultures were, on the other hand, shielded by stainless steel filings in order to dissipate the effects of a possible magnetic field. The cultures were left there until March 8, 1964.

Claus, in 1955, proposed the experiment to test whether or not the algae utilize some type of radiation in the caves through encasing them into a radiation free chamber. Pursuing this idea, lead cassettes having a wall thickness of ten centimeters were placed in "Geographer Room" and some Chlorella cultures mentioned previously were placed in them on February 6,1964 and were left in the same positions until March 8, 1964.

To test the ability of the cave waters to support large scale algal growth through the possible presence of quantities of organic material in it, test tubes filled with cave water after sterilization were inoculated with Chlorella cultures. Similarly, as in the second experimental series, some of these tubes were placed into the "Theatre Room" of the cave on January 5, 1964 while the others were kept in the laboratories as controls. The environmental characteristics of this biotope are: The room is about $10 \mathrm{~m}$ wide, $25 \mathrm{~m}$ long, relative humidity 95 to 96 percent, temperature 12.5 C., draft $2 \mathrm{~m} / \mathrm{sec}$. These values are more or less constant throughout the whole year since the largeness of the room equilibrates the fluctuations occurring in the much smaller corridors. The cultures were placed on the speleoclay having a thirty degree slope in a small wall crevice called "Treasure Chamber".

In order to get an approximate picture of the algal flora of the cave, samples were collected in sterilized $50 \mathrm{ml}$. apothecary bottles. The collections were either taken from the water of the cave streams or 
lake by submerging the bottles or scrapings were collected from the top of the speleoclay with sterile spoons. After reaching the laboratories, these bottles which contained the scraped material were filled with Knop's solution; the glass stoppers of all the bottles were substituted with cotton plugs. The collections were made on January 26, 1964, at the following localities:

1. Compass Corridor I. In a small dry pool one can find a blackish covering so called "smut", in which small, approximately $3 \mathrm{~mm}$. large spheres of unknown origin sitting on stalks can be seen. The collection contained scrapings of the "smut spots" and also the spheres.

2. Compass Corridor II. The material came from a "smut ring" with 5 to $10 \mathrm{~cm}$. widths encircling a small pond having a diameter of $20 \mathrm{~cm}$. The $\mathrm{pH}$ of the water at the time of collection was 6 .

3. "Sugar Cane". Scrapings were taken from the edge of a pool, 3-5 cm. deep, covered with blackish coating, located in a dried up portion of the river's bed. Everywhere around the locality heavy water seepage was observable. The $\mathrm{pH}$ both of the river and of the dripping waters was 6 .

4. Same as above, but the water in the small pool was thoroughly mixed and from this water containing floating silt and clay particles a scooping was taken.

5. Above the formation "Sugar Cane". On top of an approximately 15 meter high rift in the wall a fossilized bone was sticking out heavily covered with a peculiar red coating. This reddish material was scraped into a bottle.

6. Water sample from a cascade of the "Silty River" located under the "Great Traverse". The $\mathrm{pH}$ of the water was 5.

7. Water sample from "Silty Lake". The $\mathrm{pH}$ of the water was 5.

The origin of the "smut spots" or "smut ring" mentioned under localities 1, 2, and 3 are not, as yet, completely understood. In the descriptions given above, many different kinds of blackish surface layerings were described by this term.

The collections were put onto the sill of a north facing window in the laboratories and by March, 1964, the algae present in the samples developed adequately to color bluish-green the contents of the bottles. On March 6,1964, preparations from the contents of the bottles were made and the algae were identified.

\section{Results}

The gelatin tube cultures of Scenedesmus, which were placed on August 22, 1963 into the caves, after two weeks already showed observable growth to the naked eye. From the site of the stab line filament- 
ous formations could be found progressing throughout the entire culture. After five weeks portions of the gelatin became liquefied which was then decanted. During the following months the algae showed an exuberant growth, while slowly the rest of the gelatin became liquefied.

No observable difference was found among the different cultures placed into the different habitats. Though these experiments through the supply of gelatin did not give any clues as to the evaluation of algal growth in an aphotic environment since ample amounts of organic substrate were supplied them, at least one could demonstrate that the different microhabitats did not basically influence algal development.

The results of the Chlorella containing cultures prepared in Knop's solution as to their growth are combined in Table I.

Table 1

\begin{tabular}{lcccc}
\hline $\begin{array}{l}\text { Culture } \\
\text { Description }\end{array}$ & $\begin{array}{l}\text { Light transmittance } \\
\text { in Lux at beginning } \\
\text { of experiment }\end{array}$ & $\begin{array}{l}\text { Light transmittance } \\
\text { in Lux at end of } \\
\text { experiment }\end{array}$ & $\begin{array}{l}\text { Difference } \\
\text { (darkening) } \\
\text { in Lux }\end{array}$ \\
\hline Cave & $\mathbf{1 .}$ & 32.4 & 30.8 & 1.6 \\
Cultures: & 2. & 33.3 & 31.6 & 1.7 \\
& 3. & 33.3 & 30.8 & 2.5 \\
& 4. & 31.6 & 29.3 & 2.3 \\
Controls- & & & \\
wrapped: & 36.4 & 31.6 & 4.8 \\
\multicolumn{2}{c}{ unwrapped: } & 34.2 & 17.2 & 7.1
\end{tabular}

These experiments show that Chlorella indeed multiplied in the aphotic cave environment. The sample which was wrapped in black paper and was left outside shows a transitus between those kept in the cave and the other unwrapped control. The multiplication of algae in this sample is about double that measured in the cave, but only half of the normal surface control. One may speculate about the significance of this finding. If one supposes that the algae in the cave make use of certain as yet undefined radiation, then one can suppose that a greater portion of this radiation is able to penetrate the black paper than the 30 to 90 meter thick rocks forming the ceiling of the cave. The experiments show also that if such radiation indeed exists, it must have an extremely great penetrability since the difference in terms of algal development of the cave cultures and the wrapped control is rather small. A second possibility is that in the outside atmosphere there may be more molecular hydrogen available (originating from fuel 
combustion) for the utilization of algae than is accessible in the cave, which would account for the better growth of the black paper wrapped control.

No observable change was detected among those cultures which were left in a magnetic field in the cave, the controls and those which were shielded by stainless steel filings. In all three series approximately equal growth occurred. This experiment seems to indicate that the presence or absence of magnetic fields within the cave environment has no particular effect on algal growth.

In the experimental series when cave water was inoculated with Chlorella cultures, no appreciable growth could be establishde either in those tubes which were left in the cave or those which were kept on the surface. The maximum "darkening" of the surface cultures as measured on March 8, 1964, was 1.9 lux, whereas the maximum darkening of the cultures in the cave was 0.8 lux. This experiment would indicate not only that the cave waters do not contain any appreciable amount of organic material which could be utilized by the algae either in the darkness or in the presence of light, but also seems to point out the fact that the cave waters must be deficient even in the amounts of inorganic salt in comparison to the Knop's solution since in the latter definite algal growth occurred while in the former only a minimal multiplication took place.

Whereas in the previous experiments quantitatively measurable algal growth was obtained in the speleo environment, those cultures which were deposited in the lead cassettes did not multiply and eventually (after four months) died. This fact seems to indicate that the presence of simple nutrient salts in the culture medium is obviously inadequate to supply the algae with adequate energy for their growth. Also, even the small amount of organic material which might result from the dying off of certain cells cannot be enough to supply the rest of the culture with the necessary energy requirements. This last experiment seems to support the theory that the algae in the caves utilize some kind of radiation for their survival instead of making use of molecular hydrogen since exchange between the inside of the cassettes and the caves atmosphere was not hindered, in spite of the fact that a completely radiation free space is provided.

\section{Taxonomy of Algae Identified from the Cave}

\section{CYA NOPHYTA}

\section{Aphanothece castagnei (Brèb.) Rabenh.}

Thallus amorphous, mucilaginous, brownish. Cells $2 \mu$ wide, $3.5 \mu$ long, pale bluish-green. Compass Corridor II. 
Chroococcus minutus (Kütz.) Näg.

Solitary cells covered with a colorless capsule, capsule not layered. Cells yellowish in color, $8 \mu$ in diameter, including capsule; 4-6 $\mu$ without capsule. Compass Corridor I.

Chroococcus minimus (Keissel.) Lemm.

One or more encapsulated cells together in a common capsule, cells bluish-green, without capsule $3 \mu$ in diameter, with their individual capsules, about $4 \mu$. Neither the common or the individual capsules are layered. Silty Lake.

Synechocystis aquatilis Sauv.

Solitary cells with 5-6 $\mu$ diameter, without capsule, color bluishgreen. Silty Lake.

Synechococcus cedrorum Sauv.

Solitary elliptical cells, $4 \mu$ wide, $6 \mu$ long, sometimes two cells attached to each other by their ends. Bluish-green color. Silty Lake.

\section{Chamaesiphon sp.}

Approximately $40 \mu$ long, multicellular filament, which around the base is $3.5 \mu$ wide, around the top somewhat wider, 4.5-5.0 $\mu$, crosswalls can be discerned around the top portion. (The general habit of the filament somewhat resembles a Fortiea sp., but the absence of the crosswalls in the lower portion seems to preclude this possibility, further studies are required to ascertain its correct systematic position). Silty Lake.

\section{Baradlaia speluncaecola Palik}

Filaments $1.5 \mu$ wide, with varying lengths $(6.5-25 \mu)$, bluish-green, more or less rigid with side branches, the primordia of which occur as small protuberances on their sides. The cells are about $3-4 \mu$ long. The alga secretes calcium carbonate and is more or less heavily encrusted by it. Stream water under the Great Traverse; Compass Corridor I, Silty Lake.

\section{BACILLARIO PHYTA}

\section{Fragilaria sp.}

Cell $23 \mu$ long $3.5 \mu$ high. Form seen only in cantal view, therefore, no closer identification could be supplied. Compass Corridor I.

\section{Pinnularia subcapitata Greg.}

Valve elongate, sides more or less parallel with capitate ends, $27 \mu$ long, $5 \mu$ wide, 16 to 18 transapical striae in $10 \mu$, central area broad, without striation. Silty Lake. 
CHLOROPHYTA

Survival organ of a chlorophyta?

Cell sphaerical, brownish in color, with a diameter of $18 \mu$, surface covered with small protuberances. Compass Corridor III.

One has to also mention that the water of Silty Lake contains quantities of filamentous iron bacteria.

This enumeration of the algae obviously cannot be considered as the complete algal vegetation of the cave. Several new habitats have to be as yet investigated, and more extensive culturing studies are required to obtain a more complete picture of the cave's algal flora.

\section{Conclusion}

In the Introduction attention was called to the four possible mechanisms by which algae in caves might carry out their assimilatory activities. The experiments described above seemingly confirmed some and ruled out others. That algae are able to use organic material in the caves was demonstrated by the cultures containing gelatin. That symbiosis with iron bacteria could not, at least in our case, be a factor in algal assimilation was ruled out by the employment of pure algal cultures lacking any bacteria. Since only mineral nutrients were contained in the cultures of the second experimental series and still considerable algal multiplication was observed, the possibility that in this case the algae utilized organic material can be completely ruled out. Out of the two remaining possibilities, that is, chemosynthesis or some type of radiation, though it could not with absolute certainty be decided, the latter seems to be favored by the fact that the algae kept in the lead cassettes died. The studies also indicate that if symbiosis with iron bacteria, chemisynthesis or the utilization of organic material occurs at all in the assimilation of the cavernicole algae these may have an enhancing effect on their growth (as it was demonstrated in the first experimental series), but in the lack of such mechanisms algal growth still does not cease.

The preliminary studies on the composition of the algal flora of the cave resulted in the discovery of 10 species or intraspecific taxa, the majority of which belong to the Cyanophyta. Further studies, however, will undoubtedly increase this number. 


\section{ACKNOWLED GEMENT}

The author wishes to express his sincere gratitude to Professor P. Palik, Microbiological Institute, L. Eötvös University, Budapest, for calling his attention to this interesting problem and for her constant encouragement and help, especially with the identification of the algae. The instruments used during the investigations were kindly lent by Dr. Barnabas Nagy, Institute for Plant Protection, Budapest.

\section{SUMMARY}

Experiments were designed to test the ability of the aphotic speleoenvironment to support algal growth. The first series contained gelatin cultures of Scenedesmus placed in the cave at different localities in order to establish whether or not the microhabitats have any particular effect on the multiplication of the algae. No differences were found in the cultures after a three month incubation period in the cave, which could be traced to influences of microenvironmental conditions. Chlorella cultures in sterile Knop's solution showed measurable growth in the cave whereas if the cultures were installed into sterilized cave water or were shielded by lead against possible radiation effects, no appreciable growth occurred. The presence or absence of magnetic field did not noticeably influence algal development. The experiments seemed to indicate that the algae tested are able to utilize some kind of radiation in the complete darkness of the cave since, in the absence of organic material, appreciable amounts of molecular hydrogen or symbiotic activity, with iron bacteria, considerable growth occurred in a simple, strictly inorganic medium, whereas the cave waters seem to be deficient in some kind of inorganic salt required for algal nutrition. An investigation of algae living in the cave led to the determination of ten different taxa, the majority of which were Cyanophytes. Besides them, however, the cave may contain a more diversified algal population.

\section{ZUSAMMENFASSUNG}

Versuche wurden angestellt um festzustellen, ob eine lichtlose Höhlenumgebung das Wachstum der Algen ermöglicht. Die erste Versuchsreihe bestand aus Gelatin-Kulturen von Scenedesmus, die in der Höhle an verschiedenen Plätzen untergebracht wurden um festzustellen, ob die unmittelbare Umgebung einen speziellen Effekt auf die Vermehrung der Algen habe. Keine Unterschiede, die auf den Einfluß der unmittelbaren Umgebung zurückzuführen waren, wurden in den Kulturen nach dreimonatiger Inkubation in der Höhle gefunden. Chlorella-Kulturen in steriler Knop-Lösung zeigten meßbares Wachstum in der Höhle, während kein merkbares Wachstum erfolgte, wenn die Kulturen in sterilisiertem Höhlenwasser untergebracht wurden oder mit Blei gegen mögliche Strahlungseffekte abgeschirmt waren. Die Gegenwart oder Abwesenheit eines magnetischen Feldes hatte keinen merkbaren Einfluß auf die Entwicklung der Algen. Die Versuche scheinen anzudeuten, daß die geprüften Algen in der Lage waren, irgendeine Art von Strahlung in der vollkommenen Dunkelheit der Höhle auszunützen, da trotz der Abwesenheit von organischem Material oder wesent- 
lichen Quantitäten von molekularem Wasserstoff oder symbiotischer Aktivität mit Eisen-Bakterien dennoch wesentliches Wachstum erfolgte in einem einfachen und streng anorganischem Medium, während das Höhlenwasser scheinbar unzulänglich war in bezug auf irgendein anorganisches Salz, welches für die Ernährung der Algen nötig ist. Untersuchung der Algen, welche in der Höhle leben, ergab die Bestimmung von 10 verschiedenen Taxa, von welchen der größere Teil Cyanophyten waren. Es ist jedoch möglich, daß in der Höhle außerdem noch mehr verschiedenartige Algen vorkommen.

\section{REFERENCES}

Claus, G.: 1955. Algae and Their Mode of Life in the Baradla Cave at Aggtelek. Acta. Bot. Acad. Sci. Hung. 2: 1-27.

- 1960. Re-evaluation of the Genus Gomontiella. Rev. Algol. Nouv. Ser. 5: 103-111.

- 1962 a. Data on the Ecology of the Algae of Peace Cave in Hungary. Nova Hedwigia 4: 55-79.

— 1962 b. Beiträge zur Kenntnis der Algenflora der Abaligeter Höhle. Hydrobiologie 19: 192-222.

Dudich, E.: 1932. Biologie der Aggteleker Tropfsteinhöhle Baradla in Ungarn. 1-246. Wien.

Fenér, D.: 1954 Talajbiologia. (Soil Biology): 1-1264. Budapest.

JAKucs, L.: 1952. Az Aggteleki cseppköbarlang (The Dripstone Cave at Aggtelek) : 1-120. Budapest.

JA K U Cs, L., Kessle R, H. : 1962. Barlangok világa (The world of Caves) : 1-264. Budapest.

KoL, E.: 1957. Algologiai vizsgálatok a Sátorhegység jegesbarlangjában. (Algological Investigations in the Ice Cave of the Sátor Mountains) Bot. Közl. 47: 43-51.

Magdeburg, P.: 1929-1932. Organogene Kalkkonkretionen in Höhlen. Sitzungsber. Nat. Ges. Leipzig 59: 1-26.

Morton, F.: 1925. Höhlenpflanzen. Speleol. Monogr. 5: 1-16.

PALIK, P.: 1960a. Study into the Algal Flora of Caves. Hidrol. Közl. 5: $417-421$.

—: 1960b. A New Blue-green Alga from the Cave of Baradla near Aggtelek. Ann. Univ. Sci. Budapestinensis L. Eötvös nom. Sect. Biol. 3: 275-285.

Su bA, E.: 1957. Die Algen der Pálvölgyer Höhle in Ungarn. Verh. Zool.Bot Ges. Wien. 97:97-110. 